\title{
Preparation and characterization of activated carbons obtained from the waste materials impregnated with phosphoric acid(V)
}

\author{
Magdalena Zięzio $^{1}\left[\right.$ (1) $\cdot$ Barbara Charmas $^{1} \cdot$ Katarzyna Jedynak $^{2} \cdot$ Monika Hawryluk $^{1} \cdot$ Karolina Kucio $^{1}$
}

Received: 29 November 2019 / Accepted: 16 April 2020 / Published online: 5 May 2020

(c) The Author(s) 2020

\begin{abstract}
In the paper spent coffee grounds were used as a precursor to obtain activated carbons. The raw material was impregnated with phosphoric acid(V) at the different impregnations ratios: $0.5,1,1.5,2$. Carbonization was carried out according to two procedures differing in activation atmosphere $\left(\mathrm{N}_{2}\right.$ or $\left.\mathrm{CO}_{2}\right)$. The obtained activated carbons were characterized on the basis of low-temperature nitrogen adsorption/desorption, thermal analysis, potentiometric titration method, X-ray diffraction, Raman spectroscopy and scanning electron microscopy. Carbons obtained according to procedure 2 (activation in $\mathrm{CO}_{2}$ ) were characterized by better developed porosity, e.g. surface $\left(S_{\mathrm{BET}}\right.$ to $\left.720.9 \mathrm{~m}^{2} / \mathrm{g}\right)$ and pore volume $\left(V_{\mathrm{p}}\right.$ to $\left.0.334 \mathrm{~cm}^{3} / \mathrm{g}\right)$. All obtained carbons had surface acidic (mainly carboxyl) groups and exhibited the amorphous structure. The thermal analysis showed that the obtained materials were thermally stable up to the temperature $\sim 420{ }^{\circ} \mathrm{C}$.
\end{abstract}

Keywords Waste materials $\cdot$ Spent coffee grounds $\cdot \mathrm{H}_{3} \mathrm{PO}_{4}$ impregnation $\cdot$ Pyrolysis $\cdot$ Active nanocarbons

\section{Introduction}

The dynamic development of modern civilization along with the increasing amount of consumption generates a huge problem of wastes, which is a real threat to the natural environment and human health. Due to the fact that we are not able to prevent completely their production, the focus is made on the effective methods of recycling or reusing solid residues. Currently, the main way to get rid of wastes is their disposal on the landfills. However, their storage can

Magdalena Zięzio

magdalena.ziezio@poczta.umcs.lublin.pl

Barbara Charmas

barbara.charmas@poczta.umcs.lublin.pl

Katarzyna Jedynak

Katarzyna.Jedynak@ujk.edu.pl

Monika Hawryluk

monika.hawryluk@poczta.umcs.lublin.pl

Karolina Kucio

karolina.kucio@poczta.umcs.lublin.pl

1 Institute of Chemical Sciences, Faculty of Chemistry, Maria Curie-Sklodowska University, Maria Curie-Sklodowska Sq. 3, 20-031 Lublin, Poland

2 Institute of Chemistry, Jan Kochanowski University, Swietokrzyska Str. 16G, 25-406 Kielce, Poland cause serious environmental problems such as water and soil pollution (Nowicki et al. 2016; Kostecka et al. 2014). Therefore solutions that could lead to reduction in the amount of wastes or their reuse are searched for. One of the available solutions for the organic materials application is to process them into carbon materials, i.e. activated carbons (Zielińska et al. 2015) or carbon-mineral ones (Leboda et al. 2005; Skubiszewska-Zięba et al. 2012) by means of the pyrolysis procedure.

Activated carbons are produced from a variety of materials containing elemental carbon in organic combinations. Therefore, the raw materials should be characterized by the largest content of elemental carbon, the small content of volatile and inorganic substances as well as high mechanical and thermal resistance. For economical reasons the additional advantages are availability and low price. For production on a commercial scale, wood, lignin, peat, coconut shells are most often used (Alslaibi et al. 2013; Zielińska et al. 2015). In recent years the attempts have been made to obtain activated carbons from various types of waste materials, including fruit stones, corn cobs as well as solid coffee wastes (Ioannidou and Zabaniotou 2007; Reffas et al. 2010; Baquero et al. 2003).

Currently coffee is the second most valuable commodity listed on the world stock exchanges after crude oil (Illy 2002). It is very important for the production economy, 
among others, in such countries as, Brazil, Colombia, Mexico and other. Solid wastes such as coffee husks, coffee beans with defects or used coffee grounds create a number of problems that are primarily associated with their disposal, because they are produced in very large quantities (Franca and Oliveira 2009). Therefore actions aimed at reusing solid residues help to solve the problem of managing their significant amounts.

The properties of the obtained carbon materials are strongly associated with their structure which is determined by the type of starting material, the type of activating factor and the conditions of the pyrolysis process (Benaddi et al. 1998; Hesas et al. 2013; Jankowska et al. 1991). In the case of chemical activation, the starting material is impregnated or mixed with the activating agent. The most commonly used activating factors include, inter alia, $\mathrm{HNO}_{3}, \mathrm{H}_{3} \mathrm{PO}_{4}, \mathrm{NaOH}$ or $\mathrm{ZnCl}_{2}$ (Jankowska et al. 1991). Activators generally act as drainage, oxidizing and degrading agents. The activating agent introduced into the interior of the precursor particles during the impregnation step reduces the release of volatile substances at the same time hindering the particles contraction. In this way, the conversion of the precursor to activated carbon proceeds efficiently. Removal of an excessive activating agent and by-products resulting from the pyrolysis process during the washing step leads to a material with a well-developed surface and a porous structure (Girgis and El-Hendawy 2002).

Phosphoric $\operatorname{acid}(\mathrm{V})$ is one of the most commonly used activating agents and it is characterized by two very important functions: it supports/promotes the pyrolytic transformation of the starting material and participates in the organization of the cross-linked structure of carbonaceous material. According to the literature data (Liou and $\mathrm{Wu}$ 2009), the mechanism of the starting material activation using $\mathrm{H}_{3} \mathrm{PO}_{4}$ can take place in three stages:

1. decomposition of organic matter into semi-finished products with a lower molar mass and release of gaseous, volatile substances in the initial stage of activation;

2. distribution of intermediate compounds-formation of tar and coal fraction. In this stage $\mathrm{H}_{3} \mathrm{PO}_{4}$ begins to break down;

3. char reaction with $\mathrm{P}_{2} \mathrm{O}_{5}$ causing opening/expansion of the pores.

In the case of activation with phosphoric acid, pyrolysis is most often carried out at temperatures of $400-700{ }^{\circ} \mathrm{C}$ (Baquero et al. 2003; Reffas et al. 2010), however, according to the literature reports, a higher temperature range, up to $800^{\circ} \mathrm{C}$, is also often used (Arampatzidou and Deliyanni 2016; Kang et al. 2011).

Studies on the mechanisms of activation process are also proposed by $\mathrm{Li}$ et al. (2015). They stated that $\mathrm{H}_{3} \mathrm{PO}_{4}$ acts as an acid catalyst to promote bond cleavage reactions and as a reactant in the formation of crosslinks via the cyclization and condensation processes. $\mathrm{H}_{3} \mathrm{PO}_{4}$ could also combine with organic matter in bio wastes to form phosphate and polyphosphate bridges that connect and crosslink polymer fragments. Moreover, some of these phosphate groups remain on the carbon surface after the washing step. They proposed a likely activation mechanism (Eqs. 1-6) and described the changes that the acid undergoes in the specific temperature ranges:

- In the temperature range $100-400{ }^{\circ} \mathrm{C}$ :

$$
\begin{aligned}
& 2 \mathrm{H}_{3} \mathrm{PO}_{4} \rightarrow \mathrm{H}_{4} \mathrm{P}_{2} \mathrm{O}_{7}+\mathrm{H}_{2} \mathrm{O} \\
& 3 \mathrm{H}_{3} \mathrm{PO}_{4} \rightarrow \mathrm{H}_{5} \mathrm{P}_{3} \mathrm{O}_{10}+2 \mathrm{H}_{2} \mathrm{O} \\
& n \mathrm{H}_{3} \mathrm{PO}_{4} \rightarrow \mathrm{H}_{n+2} \mathrm{P}_{n} \mathrm{O}_{3 n+1}+(n-1) \mathrm{H}_{2} \mathrm{O}
\end{aligned}
$$

The adsorbed water is released and $\mathrm{H}_{3} \mathrm{PO}_{4}$ dehydrated. As a result of the functional groups breakdown $\mathrm{CO}_{2}$ and $\mathrm{CO}$ are released.

- In the temperature range $400-700{ }^{\circ} \mathrm{C}$ :

$$
\begin{aligned}
& \mathrm{H}_{n+2} \mathrm{P}_{n} \mathrm{O}_{3 n+1} \rightarrow \mathrm{P}_{4} \mathrm{O}_{10}+\mathrm{H}_{2} \mathrm{O} \\
& \mathrm{P}_{4} \mathrm{O}_{10}+2 \mathrm{C} \rightarrow \mathrm{P}_{4} \mathrm{O}_{6}+2 \mathrm{CO}_{2}
\end{aligned}
$$

As a result of $\mathrm{H}_{3} \mathrm{PO}_{4}$ dehydration, $\mathrm{H}_{2} \mathrm{O}$ is released, the resulting $\mathrm{P}_{4} \mathrm{O}_{10}$, as a strong oxidant, reacts with carbon to create new and widening existing pores, releasing $\mathrm{CO}_{2}$ and as a result of the surface functional groups decomposition $\mathrm{CO}$ is created.

- In the temperature range $700-800^{\circ} \mathrm{C}$ :

$$
\mathrm{P}_{4} \mathrm{O}_{10} / \mathrm{P}_{4} \mathrm{O}_{6}+\mathrm{CH}_{x} \rightarrow \mathrm{PH}_{3}+\mathrm{CO}_{2} / \mathrm{CO}
$$

$\mathrm{PH}_{3}$ is formed, the amounts of $\mathrm{CO}_{2}$ and $\mathrm{CO}$ released as a result of reactions and the breakdown of functional groups increase very intensively ( $\mathrm{Li}$ et al. 2015). All these processes occur in the organic material pyrolysis stage.

Myglovets et al. (2014) claims that during the carbonization processes breaking of less stable bonds releases the volatile fraction of raw material. The thermal degradation of the organophosphorus compounds as well as formation of volatile phosphorous-containing compounds (phosphorus(V) oxide or elemental phosphorus) took place as a result of reduction of the phosphates. Then the carbon matter of basic porosity enriched in carbon rings is obtained. During activation carbon dioxide is usually preferred to steam because of 
its low reactivity $(\Delta H>0)$ that permits controlling oxidation rates so that uniform porosity is developed. The literature data concerning the oxidation protection provided by phosphorous compounds showed that the phosphorus compounds can evaporate from the carbon surface at temperatures higher than $800{ }^{\circ} \mathrm{C}$ (McKee 1991; Oh and Rodriguez 1993). Formation of elemental phosphorus was observed during the phosphoric acid activation of polymer fibers (Puziy et al. 2002) and during pyrolysis of phosphorus-containing resins (Puziy 2011). The reaction products allow the surface to develop and create pores.

As it was shown (Puziy 2011) the activation at temperatures above $750{ }^{\circ} \mathrm{C}$ occurs spontaneously. A decrease in the yield at temperatures higher than $800^{\circ} \mathrm{C}$ was observed for carbons prepared from other carbonaceous precursors, including various polymers and fruit stones. As follows from the literature data pyrolysis involves a series of both exothermic and endothermic processes (Yang and Roy 1996). During the pyrolysis process, organic matters are cracked down into smaller fractions which is an exothermic reaction (Yang and Roy 1996). As the temperature increases, secondary and volatile products are formed. Such reaction is endothermic (Oyedun et al. 2013; Yang and Roy 1996). The multi-stage pyrolysis process can save energy and the processing time enabling greater efficiency of carbon production (Lee et al. 2017; Oyedun et al. 2013).

The aim of the paper was to apply solid coffee residues (spent coffee grounds) as precursors to obtain activated carbon. To activate the starting material, phosphoric acid(V) was used at various impregnation ratios. Carbonization of the starting material was conducted under different conditions ( $\mathrm{N}_{2}$ or $\mathrm{CO}_{2}$ atmosphere). The obtained activated carbons were characterized on the basis of low-temperature nitrogen adsorption/desorption, thermal analysis, potentiometric titration method, X-ray diffraction (XRD), Raman spectroscopy and scanning electron microscopy (SEM). It was shown that the proposed procedures made it possible to obtain microporous active carbons with a developed surface, having surface functional groups mainly of acid nature. The research shows that the structure of the materials changed after the $\mathrm{H}_{3} \mathrm{PO}_{4}$ activation. This indicates that phosphoric acid promotes transformation of carbon matter to the thermally stable one. The thermal stability of the products depends on the presence of activating agent $\left(\mathrm{CO}_{2}\right)$.

\section{Experimental}

\section{Materials and methods}

All used reagents: methanol (Merck) as well as phosphoric $\operatorname{acid}(\mathrm{V})\left(85 \mathrm{wt} \%, d=1.71 \mathrm{~g} / \mathrm{cm}^{3}\right), \mathrm{HCl}(35 \%), \mathrm{NaOH}$,
$\mathrm{Na}_{2} \mathrm{CO}_{3}$ and $\mathrm{NaHCO}_{3}$ are analytical grade obtained from Standard (Poland).

\section{Preparation of starting material}

Spent coffee grounds (Arabica) were collected from households. The starting material was washed with redistilled water to remove impurities from various coffee brewing processes and dust. Then they were dried at $100{ }^{\circ} \mathrm{C}$ for $24 \mathrm{~h}$. The 1-2 $\mathrm{mm}$ fraction was used for further research.

\section{Impregnation of starting material}

The dried and sieved material was impregnated with phosphoric $\operatorname{acid}(\mathrm{V})$ at the different impregnation ratios. The amount of $\mathrm{H}_{3} \mathrm{PO}_{4}$ was characterized by the degree of impregnation $(I)$ determined by the formula (Eq. 7):

$I=\frac{m_{\mathrm{a}}}{m_{\mathrm{p}}}$,

where $m_{\mathrm{a}}$-the mass of acid $\left(\mathrm{H}_{3} \mathrm{PO}_{4}\right)$ determined using the acid density $(\mathrm{g}), m_{\mathrm{p}}$ - the mass of precursor $(\mathrm{g})$.

For impregnation, the waste material $(100 \mathrm{~g})$ was placed in a beaker. The specified amount of acid was diluted with redistilled water to a volume of $150 \mathrm{ml}$. The prepared solution was added to the material. There were used the following impregnation degree values: $0.5 ; 1 ; 1.5 ; 2$. To increase the penetration of the material through the acid, the ultrasonic assistance was applied in three 10-min cycles, followed by a $10-$ min break. Then the beaker with the impregnated material was placed on a shaker $\left(30^{\circ} \mathrm{C} / 24 \mathrm{~h} / 60 \mathrm{rpm}\right)$. After 24-h impregnation the material was rinsed with a small amount of redistilled water $(400 \mathrm{ml}$, to remove acid from the intergranular spaces) and then dried $\left(100^{\circ} \mathrm{C} / 12 \mathrm{~h}\right)$.

\section{Carbonization}

Carbonization was carried out according to the following temperature program:

- 20-400 ${ }^{\circ} \mathrm{C}$ : temperature rise by $10{ }^{\circ} \mathrm{C} / \mathrm{min}$

- $400{ }^{\circ} \mathrm{C}$ : annealing of the sample for $1 \mathrm{~h}$

- $400-800{ }^{\circ} \mathrm{C}$ : temperature rise by $10{ }^{\circ} \mathrm{C} / \mathrm{min}$

- $800{ }^{\circ} \mathrm{C}$ : annealing of the sample for $3 \mathrm{~h}$

- cooling: $1 \mathrm{~h}$

Carbonization was conducted in two variants. The first variant (procedure 1) was conducted in a nitrogen atmosphere (nitrogen flow $150 \mathrm{ml} / \mathrm{min}$ ). In variant 2 (procedure 2) at $800{ }^{\circ} \mathrm{C} \mathrm{CO}_{2}$ was used as an oxidizing agent. The aim of $\mathrm{CO}_{2}$ application was the additional surface development.

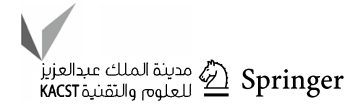


The determinations of the obtained samples are as follows:

- the number in the sample name indicates the impregnation ratio $(I)$, i.e. $0.5,1,1.5,2$;

- the subscript number indicates the procedure number, i.e. 1 or 2 .

For example, AC- $0.5_{2}$-indicates that the sample was obtained using an impregnation ratio of 0.5 and procedure 2.

For comparison the starting waste material was also subjected to pyrolysis according to procedure 1 (without the impregnation, designated as AC).

After pyrolysis the activated carbons were washed with hot distilled water to obtain a neutral $\mathrm{pH}$. After washing the obtained materials were dried at $100{ }^{\circ} \mathrm{C}$ for $12 \mathrm{~h}$.

The carbonization process of impregnated materials was conducted using the multi-stage pyrolysis (1-h isothermal stage at $\left.400{ }^{\circ} \mathrm{C}\right)$. In the conducted research it was necessary to slow down the pyrolysis process due to the formation of significant amounts of by-products (in the form of vapours). This effect was precisely achieved by using an isotherm at $400{ }^{\circ} \mathrm{C}$.

\section{Methods}

\section{Nitrogen adsorption/desorption}

Porous structure characteristics were determined for the obtained materials using the low-temperature nitrogen adsorption-desorption (77.2 K, Micrometrics, ASAP 2405, Norcross, GA, USA). The specific surface area $\left(S_{\mathrm{BET}}\right)$ was determined according to the Brunauer-Emmett-Teller equation (BET) (Gregg and Sing 1982). From the isotherms shape at a relative pressure of $p / p_{0} \sim 0.99$ the total volume of sorption pores $\left(V_{\mathrm{p}}\right)$ was determined. The pore size distribution-PSDV $(\mathrm{d} V / \mathrm{d} R=f(R))$ was calculated based on the nitrogen adsorption data. The SCR method (self-consistent regularization procedure under the nonnegativity condition $\left(f\left(R_{\mathrm{p}}\right)>0\right.$ at any pore radius $\left.R\right)$ was used for the calculations (Gun'ko and Mikhalovsky 2004; Gun'ko and Turov 2013; Gun'ko 2014). The value of the regularization parameter was $\alpha=0.01$. A slit-like pores model, typically used for the analysis of structural characteristics of carbon adsorbents was assumed (Gun'ko and Mikhalovsky 2004; Gregg and Sing 1982). The share of micropores $\left(S_{\text {micro }}, V_{\text {micro }}, R_{p}<1 \mathrm{~nm}\right)$ and mesopores $\left(S_{\text {meso }}, V_{\text {meso }}, 1 \mathrm{~nm}<R_{\mathrm{p}}<25 \mathrm{~nm}\right.$ ) was determined based on the obtained data (Gun'ko and Do 2001; Gun'ko and Turov 2013; Gun'ko 2000).

\section{Thermal analysis}

To assess the thermal stability of the obtained activated carbons, thermal analysis was performed (Derivatograph-C, F. Paulik, L. Erdey, MOM, Budapest, Hungary). Measurements were made in an air atmosphere in the temperature range of $20-800{ }^{\circ} \mathrm{C}$ with a temperature rise by $10{ }^{\circ} \mathrm{C} / \mathrm{min} . \mathrm{Al}_{2} \mathrm{O}_{3}$ was used as the reference substance. The weights of the tested samples were about $30 \mathrm{mg}$. TG, DTG and DTA curves were recorded during the analysis. The initial waste material (sample designated Spent ${ }_{\text {ini }}$ ) as well as the carbons obtained from non-impregnated (sample AC) and impregnated (AC- $I_{\text {procedure }}$ ) wastes were tested.

\section{Bulk density}

Bulk density determination procedures are given in relevant standards (ASTM D2854-09 2014). In the presented investigations in order to determine the bulk density $(\rho)$ in the measuring cylinder with a volume of $10 \mathrm{~cm}^{3}$, activated carbon samples were placed so that they occupied a volume in the range of $2-4 \mathrm{~cm}^{3}$. Before testing, the mass of each sample $\left(m_{\mathrm{s}}\right)$ was precisely recorded. Then the cylinder was tapped against a hard surface about 50 times to "compact" the carbonaceous material and the volume $\left(V_{\mathrm{p}}\right)$ was read. The analysis was repeated three times for each sample. The bulk density was calculated based on the equation:

$\rho=\frac{m_{\mathrm{s}}}{V_{\mathrm{p}}}$,

where $\rho$-the bulk density $\left(\mathrm{g} / \mathrm{cm}^{3}\right), m_{\mathrm{s}}$-the sample mass $(\mathrm{g}), V_{\mathrm{p}}$-the volume of the sample $\left(\mathrm{cm}^{3}\right)$.

\section{Total pore and macropore volumes}

In order to determine the total pore $\left(V_{\text {total }}\right)$ and the macropore $\left(V_{\text {macro }}\right)$ volumes, a method of filling the pores of the tested material using methanol was used. Each of the activated carbons was prepared in an amount of 3 representative samples weighing about $0.2 \mathrm{~g}$. Then methanol was added using a 1 $\mathrm{cm}^{3}$ glass burette until a compact carbon sample structure was obtained. This condition corresponds to the filling of mesoand macropores as well as inter-grain spaces. For the methanol to penetrate thoroughly into the pores, the whole process was supported by ultrasounds. Based on the obtained results the total pore volume $\left(V_{\text {total }}\right)$ and the macropore volume $\left(V_{\text {macro }}\right)$ were determined in accordance with the relationships (Eqs. 8, 9). The above figures were calculated using the formulae:

$V_{\text {total }}=\frac{V_{\mathrm{MeOH}}}{m_{\mathrm{s}}}$, 
$V_{\text {macro }}=V_{\text {total }}-V_{\mathrm{p}}$

where $V_{\text {total }}$-the total pore volume $\left(\mathrm{cm}^{3} / \mathrm{g}\right), V_{\mathrm{MeOH}}$-the methanol volume $\left(\mathrm{cm}^{3}\right), V_{\text {macro }}$ - the macropores volume $\left(\mathrm{cm}^{3} / \mathrm{g}\right), V_{\mathrm{p}}$ - the sorption pore volume $\left(\mathrm{cm}^{3} / \mathrm{g}\right), m_{\mathrm{s}}$ - the sample mass (g).

\section{Potentiometric titration method}

Measurements were made with a 716 DMS Titrino device (Metrohm), Switzerland. In order to make measurements for each of the obtained activated carbons, representative samples of approximately $0.2 \mathrm{~g}$ were prepared. Titrations for each sample were performed three times. Each sample was flooded with a suitable solution $\left(0.05 \mathrm{~N}, V=10 \mathrm{~cm}^{3}\right)$ : $\mathrm{NaOH}, \mathrm{HCl}, \mathrm{Na}_{2} \mathrm{CO}_{3}$ and $\mathrm{NaHCO}_{3}$.

Then the suspensions were put on a shaker $\left(25{ }^{\circ} \mathrm{C} / 24 \mathrm{~h} / 60 \mathrm{rpm}\right)$. Next after sedimentation $3 \mathrm{~cm}^{3}$ of appropriate solution was taken into a measuring cell which was diluted with redistilled water $\left(20 \mathrm{~cm}^{3}\right)$ and titrated while stirring vigorously.

The $\mathrm{Na}_{2} \mathrm{CO}_{3}$ and $\mathrm{NaHCO}_{3}$ solutions were titrated with $\mathrm{HCl}$. The $\mathrm{NaOH}$ solution was used as a titrant to titrate $\mathrm{HCl}$. For the determination of $\mathrm{NaOH}$ concentration, the reverse titration method was used (Boehm et al. 1964).

\section{Raman spectroscopy}

To identify organic compounds in the obtained materials an analysis was performed using Raman spectroscopy in Via Reflex, Renishaw with the Raman dispersive system using the $514 \mathrm{~nm}$ argon laser. The application of $1.4 \mathrm{~mW}$ of laser power prevented from sample overheating.

\section{XRD-diffraction (XRD)}

The analysis of the phase composition of the obtained carbon material was made with the powder diffractometer PANalytical Empyrean using the $\mathrm{Cu}-\mathrm{K}_{\alpha}$ radiation $(40 \mathrm{kV}$, $25 \mathrm{~mA}, \lambda=1.541874)$. The analysis of the crystal structure was carried out using the PDF-4 + 2019 Database.

\section{Scanning electron microscopy (SEM)}

The morphology of the samples was analyzed using a DualBeam Quanta 3D FEG FEI microscope under the conditions of low vacuum at an accelerating voltage of $5 \mathrm{kV}$. The quantitative and qualitative analyses were performed using the energy-dispersive X-ray spectroscopy (SEM/EDX, acceleration: $15 \mathrm{kV}$ ).

\section{Results and discussion}

\section{Textural characteristics}

The preliminary studies showed that the pyrolysis of nonimpregnated coffee waste under the conditions described in the paper was not effective. The residue of volatile, noncarbonized parts was so large that it was impossible to determine the structural parameters of such a material. Therefore further research was carried out for impregnated waste. Table 1 presents the data about the degree of carbonaceous materials combustion in the ongoing pyrolysis processes. As it follows from the data in the table, an increase in the degree of combustion was observed along with an increase in the degree of impregnation with phosphoric acid(V). The burning rate fluctuated around $66-76 \%$. Such a high performance result of the burning process indicates a significant loss of carbonaceous matter and also suggests surface development

Table 1 Structural characteristics of the obtained adsorbents

\begin{tabular}{llllllllllllllllll}
\hline Sample & $S_{\text {BET }}$ & $S_{\text {micro }}$ & $\% S_{\text {micro }}$ & $S_{\text {meso }}$ & $\% S_{\text {meso }}$ & $V_{\mathrm{p}}^{*}$ & $V_{\text {micro }}$ & $\% V_{\text {micro }}$ & $V_{\text {meso }}$ & $\% V_{\text {meso }}$ & $V_{\text {total }} * *$ & $V_{\text {macro }} * *$ & $R_{\text {av }}$ & $\rho$ & $\%$ & $\Delta w$ \\
\hline AC- $1_{1}$ & 269.8 & 122.3 & 91.4 & 11.5 & 8.6 & 0.123 & 0.106 & 86.5 & 0.017 & 13.5 & 0.246 & 0.123 & 0.9 & 0.46 & 66.1 & 0.504 \\
AC-1.5 & 400.5 & 231.7 & 90.0 & 25.6 & 10.0 & 0.183 & 0.154 & 84.1 & 0.029 & 16.6 & 0.340 & 0.185 & 1.0 & 0.46 & 69.3 & 0.358 \\
AC-2 1 & 464.2 & 277.9 & 89.3 & 33.5 & 10.7 & 0.213 & 0.176 & 82.9 & 0.036 & 16.8 & 0.306 & 0.094 & 1.1 & 0.56 & 69.6 & 0.329 \\
AC-0.5 & 407.8 & 317.3 & 89.7 & 36.5 & 13.3 & 0.188 & 0.156 & 83.2 & 0.030 & 16.1 & 0.476 & 0.288 & 1.4 & 0.39 & 70.4 & 0.132 \\
AC- $2_{2}$ & 466.6 & 309.0 & 90.0 & 34.5 & 10.0 & 0.213 & 0.179 & 83.9 & 0.033 & 15.7 & 0.448 & 0.235 & 1.2 & 0.41 & 70.1 & 0.264 \\
AC-1.5 & 614.8 & 435.2 & 88.5 & 56.7 & 11.5 & 0.283 & 0.231 & 81.4 & 0.051 & 18.1 & 0.456 & 0.173 & 1.3 & 0.41 & 73.5 & 0.223 \\
AC-2 2 & 720.9 & 456.9 & 87.3 & 66.4 & 12.7 & 0.334 & 0.265 & 79.6 & 0.067 & 20.0 & 0.515 & 0.180 & 1.2 & 0.48 & 76.9 & 0.274 \\
\hline
\end{tabular}

$S_{B E T}$ the specific surface area $\left(\mathrm{m}^{2} / \mathrm{g}\right), S_{\text {micro }}$ the micropores surface $\left(\mathrm{m}^{2} / \mathrm{g}\right), \% S_{\text {micro }}$ the percentage of micropores surface $\left(S_{\text {micro }} / S_{\mathrm{BET}}\right) \cdot 100 \%, S_{\text {meso }}$ the mesopores surface $\left(\mathrm{m}^{2} / \mathrm{g}\right), \% S_{\text {meso }}$ the percentage of mesopores surface $\left(S_{\text {meso }} / S_{\mathrm{BET}}\right) \cdot 100 \%, V_{p}^{*}$ the pore volume determined using the data from $\mathrm{N}_{2}$ adsorption/desorption $\left(\mathrm{cm}^{3} / \mathrm{g}\right), V_{\text {micro }}$ the micropores volume $\left(\mathrm{cm}^{3} / \mathrm{g}\right), \% V_{\text {micro }}$ the percentage of micropores volume $\left(V_{\text {micro }} / V_{\mathrm{p}}^{*}\right) \cdot 100 \%$, $V_{\text {meso }}$ the mesopores volume $\left(\mathrm{cm}^{3} / \mathrm{g}\right), \% V_{\text {meso }}$ the percentage of mesopores volume $\left(V_{\text {meso }} / V_{\mathrm{p}}^{*}\right) \cdot 100 \%, V_{\text {total }}{ }^{* *}$ the pore volume determined using methanol $\left(\mathrm{cm}^{3} / \mathrm{g}\right), V_{\text {macro }}{ }^{* *}$ the macropores volume, $V_{\text {macro }}{ }^{* *}=V_{\text {total }}{ }^{* *}-V_{\mathrm{p}}{ }^{*}\left(\mathrm{~cm}^{3} / \mathrm{g}\right), R_{a v}$ the average pore radius $(\mathrm{nm}), \rho$ the bulk density $\left(\mathrm{g} / \mathrm{cm}^{3}\right)$, $\%_{B}$ the degree of burning, $\Delta w$ the deviation from the assumed pore model 
and significant porosity of the obtained materials. At higher impregnation degree the yield of the pyrolysis decreases. The increase in the values of structural parameters was also reported in the literature. Boudrahem et al. (2011) studied the effect of two activating agents $\left(\mathrm{H}_{3} \mathrm{PO}_{4}\right.$ and $\left.\mathrm{ZnCl}_{2}\right)$ on the development of the surface and porous structure of activated carbons and pointed out to the importance of the quantity and type of the activator. They observed a significant increase in $S_{\mathrm{BET}}, V_{\text {tot }}$ and $V_{\text {mes }}$ values with the increasing impregnation degree $(I)$. They showed better efficiency of $\mathrm{H}_{3} \mathrm{PO}_{4}$ as the activating agent (obtaining carbons with $S_{\mathrm{BET}}=1003 \mathrm{~m}^{2} / \mathrm{g}$ at $\left.I=100 \%\right)$ than $\mathrm{ZnCl}_{2}\left(S_{\mathrm{BET}}=889 \mathrm{~m}^{2} / \mathrm{g}\right.$ for $I=100 \%$ ). In turn, Reffas et al. (2010) found that the porous structure and surface chemistry of carbons can be easily controlled by changing the impregnation coefficient. Using $I=180 \mathrm{wt}$.\% they obtained mesoporous carbon with the $S_{\mathrm{BET}}=925 \mathrm{~m}^{2} / \mathrm{g}$ and $V_{\mathrm{p}}=0.7 \mathrm{~cm}^{3} / \mathrm{g}$. The same relationship was observed by Baquero et al. (2003), who using $I=150 \%$ obtained carbons with the $S_{\mathrm{BET}}$ area $=1402 \mathrm{~m}^{2} / \mathrm{g}$ and $V_{\mathrm{p}}=1.25 \mathrm{~cm}^{3} / \mathrm{g}$.

Table 1 shows the structural parameters of the obtained materials. For the materials prepared according to procedure 1, the specific surface area was from 269.8 to $464.2 \mathrm{~m}^{2} / \mathrm{g}$, while the pore volume ranged from 0.123 to $0.213 \mathrm{~cm}^{3} / \mathrm{g}$. These materials were characterized by a microporous structure $\left(S_{\text {micro }}, V_{\text {micro }}\right.$, Table 1$)$. The micropores contribution was about $90 \%$ of the surface $\left(\% S_{\text {micro }}\right.$, Table 1$)$ and $~ 84 \%$ of their volume ( $\% V_{\text {micro }}$, Table 1$)$. This is also indicated by the shape of isotherms belonging to type I (Fig. 1a) according to the IUPAC classification (Sing 1982) and the pore volume distribution curves (Fig. 2a).

For additional activation and surface development, a series of materials was treated using $\mathrm{CO}_{2}$ as the oxidizing agent (procedure 2). The process was carried out in accordance with the temperature program used in procedure 1 and the additional modification was made only in the annealing stage at $800{ }^{\circ} \mathrm{C}$ (for $3 \mathrm{~h}$ ). The obtained materials were characterized by a more developed surface $\left(S_{\mathrm{BET}} \sim 407.8\right.$ to $720.9 \mathrm{~m}^{2} / \mathrm{g}$ ) and a pore volume (from 0.188 to $0.334 \mathrm{~cm}^{3} / \mathrm{g}$, Table 1). Similar to the carbons obtained according to procedure 1 , these materials have a predominant number of micropores (about $88 \%$ of the surface or volume, $\% S_{\text {micro }}$, $\% V_{\text {micro }}$, Table 1) and the shape of type I isotherms (Fig. 1b). On the pore volume distribution curves (Fig. 2b) one can observe the peaks indicating the presence of pores with $R_{\text {dom }} \sim 0.8 \mathrm{~nm}$.
Fig. 1 Isotherms of nitrogen low-temperature adsorption/desorption for the activated carbons obtained according to procedure 1 (a) and procedure 2 (b)
Fig. 2 Pore volume distribution curves for the activated carbons obtained according to procedure 1 (a) and procedure 2 (b)
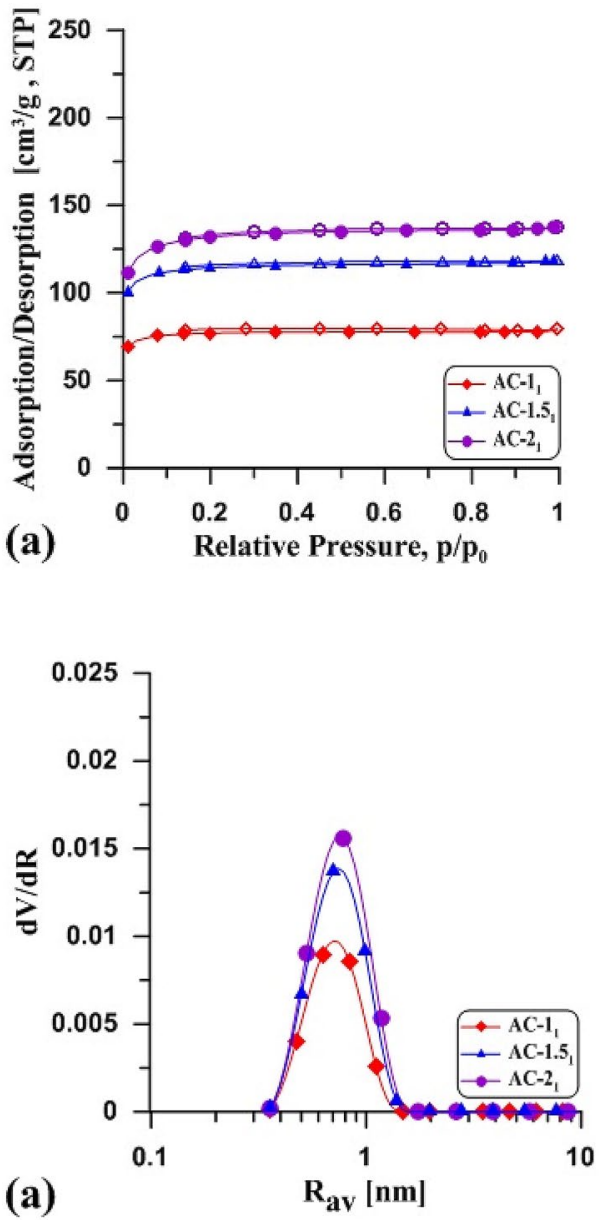

The share of mesopores in all tested materials is very small. For the adsorbents obtained according to procedure 1 , the surface of mesopores is about $11.5-33.5 \mathrm{~m}^{2} / \mathrm{g}$ which is $\sim 10 \%$ (Table 1). In the case of $\mathrm{CO}_{2}$ modified materials, the surface of mesopores is slightly larger $\left(S_{\text {meso }} \sim 36.5\right.$ to 66.4 $\left.\mathrm{m}^{2} / \mathrm{g}\right)$, however, the share of mesopores surface $\left(\% S_{\text {meso }}\right.$, $\% V_{\text {meso }}$, Table 1$)$, due to the intense surface development $\left(S_{\mathrm{BET}}\right)$ is comparable.

The volume of sorption pores $\left(V_{\text {total }}\right)$ and macropores $\left(V_{\text {macro }}\right)$ was determined for all tested materials, using methanol as the adsorbate (Table 1). These values are of significant importance as the obtained carbons can be effective adsorbents for removal of pollutants from the aquatic environment. The materials obtained according to procedure $1 \mathrm{had}$ a sorption capacity of $0.246-0.306 \mathrm{~cm}^{3} / \mathrm{g}$ while the volume of macropores was about $0.1 \mathrm{~cm}^{3} / \mathrm{g}$. The use of $\mathrm{CO}_{2}$ as an oxidizing agent proved to be very effective. The comparison of the materials obtained based on both procedures 1 and 2 shows an almost twofold increase in the total pore volume $\left(V_{\text {total }}, V_{\text {macro }}\right.$, Table 1) using $\mathrm{CO}_{2}$. The discussed carbons had a sorption capacity of $0.448-0.515 \mathrm{~cm}^{3} / \mathrm{g}$, while the volume of macropores was $0.173-0.228 \mathrm{~cm}^{3} / \mathrm{g}$. The significant $V_{\text {total }}$ values resulted from the fact that methanol fills both the accessible sorption pores and the inter-grain spaces between the carbon particles.

With the impregnation degrees increase, a slight increase in the average pore radius $R_{\mathrm{av}}$ can be observed. However, the changes are small $\left(R_{\mathrm{av}}\right.$, Table 1$)$. The use of $\mathrm{CO}_{2}$ (procedure 2) resulted from the fact that the pore radii of these materials are slightly larger. This also entails systematic changes in bulk density. These values are similar $\left(0.39-0.56 \mathrm{~g} / \mathrm{cm}^{3}\right)$ to those parameters obtained for other biochars, e.g. $0.57 \mathrm{~g} /$ $\mathrm{cm}^{3}$ for charcoal from oak or $0.28-0.44 \mathrm{~g} / \mathrm{cm}^{3}$ for charcoal from pine (CRC Handbook of Chemistry and Physics 2003).

In the case of sample AC- $0.5_{1}$, due to the very low degree of carbonization, determination of structural parameters was impossible.

The bulk density of the materials obtained according to procedure 1 is slightly higher than that for the second series of materials, indicating a larger surface development affected by the $\mathrm{CO}_{2}$ activation (procedure 2). Modification of porous structure resulted in different pore sizes which is evidenced in the PSD bands broadening and height (Fig. 2a, b) and the results from some deviations in the applied model. This is confirmed by the values $\Delta w$ (Table 1) indicating a wide range of deviations from the assumed model of pores.

\section{XRD analysis}

Figure 3 shows the XRD spectra of selected activated carbons. The broad fuzzy peaks $\mathrm{C}(002)$ at $2 \theta=15^{\circ}-30^{\circ}$ indicate that the carbon has mainly an amorphous structure. It follows that the annealing of the material at a temperature

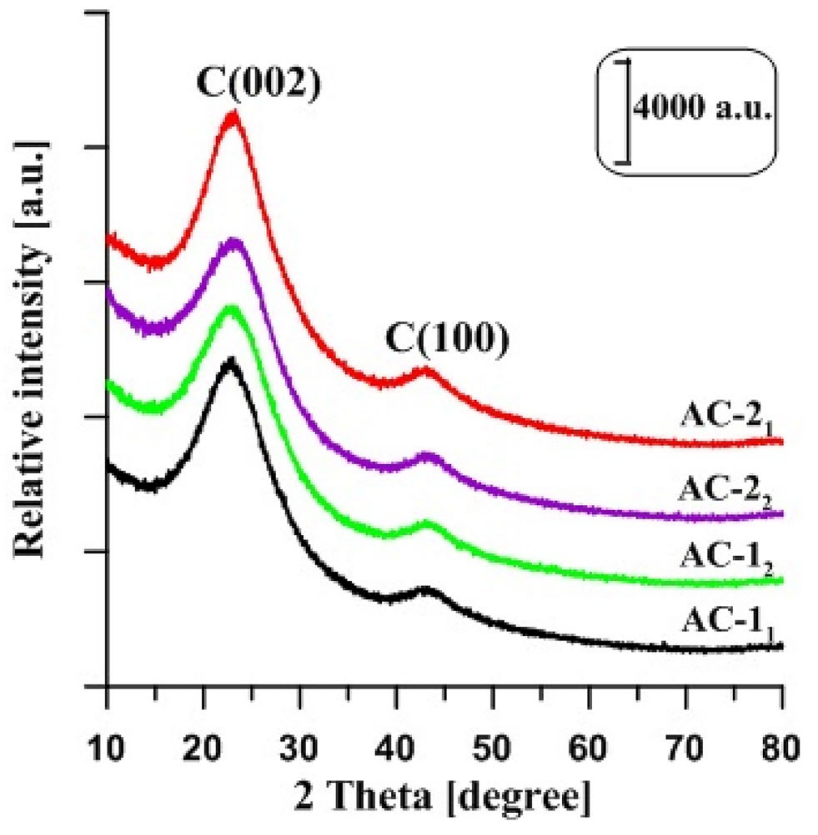

Fig. 3 XRD spectra of the selected activated carbons

of $800{ }^{\circ} \mathrm{C}$ did not create the crystal structure. The low and wide $\mathrm{C}(100)$ diffraction peaks $\left(2 \theta=40^{\circ}-50^{\circ}\right)$ can be related to the $\alpha$ axis of the graphite structure which may indicate that the tested materials contain a number of graphite planes (Okamura et al. 2006; Liu et al. 2010). Changes in the impregnation degree or pyrolysis conditions did not cause significant changes in the materials structure. These observations are consistent with the results obtained from the Raman spectrum analysis (further given in the paper).

\section{Raman spectroscopy}

Figure 4 presents the Raman spectra for the selected activated carbons. The method is the most widely used to distinguish the bonding type, domain size, and internal stress in amorphous and nanocrystalline carbon materials. Commonly carbon materials have wide bands in the range $1300-1600 \mathrm{~cm}^{-1}$. The band around $1350 \mathrm{~cm}^{-1}$ (D band) associated with nanocrystalline carbon corresponds to the vibrations of the breathing mode in the aromatic carbon ring while the $\mathrm{G}$ band visible at $\sim 1580 \mathrm{~cm}^{-1}$, associated with amorphous carbon materials, originates from the stretching vibrations of $s p^{2}$ carbon pairs present both in rings and chain structures. The most important parameters determining the type of carbon material structure are the location of the $\mathrm{G}$ band and the ratio of intensity of the $\mathrm{D}$ to $\mathrm{G}$ bands. From the relationships between these quantities it is possible to determine the content of the $s p^{3}$ phase and the type of structure prevailing in the tested material (Ferrari and Robertson 2004). Figure 4 shows that for the materials obtained

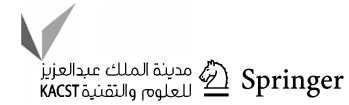




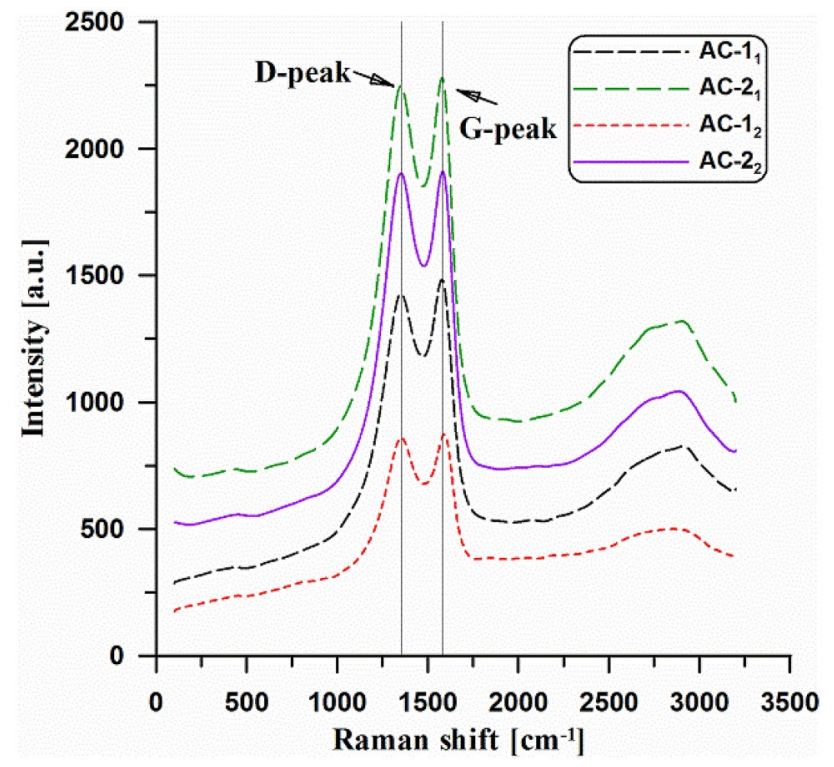

Fig. 4 Raman spectra of the selected active carbons

Table 2 The $\mathrm{G}$ bands location and intensity ratio

\begin{tabular}{lll}
\hline Sample & $\begin{array}{l}\text { G band loca- } \\
\text { tion }\left(\mathrm{cm}^{-1}\right)\end{array}$ & $I_{\mathrm{D}} / I_{\mathrm{G}}$ \\
\hline $\mathrm{AC}-1_{1}$ & 1587 & 0.92 \\
$\mathrm{AC}^{2} 2_{1}$ & 1591 & 0.90 \\
$\mathrm{AC}-1_{2}$ & 1602 & 0.91 \\
$\mathrm{AC}-2_{2}$ & 1592 & 0.91 \\
\hline
\end{tabular}

according to both procedures, an increase in the impregnation degree caused a significant increase in the intensity of $D$ and $G$ bands, however, the changes in the of D and $G$ bands location were not observed. In addition, the intensity bands ratio of $I_{\mathrm{D}} / I_{\mathrm{G}}$, as the ratio of peak heights (Ferrari and Robertson 2000) for the tested materials is similar ( $~ 0.91$, Table 2). It is known that the Raman spectrum depends essentially on the ordering of $s p^{2}$ and $s p^{3}$ fractions, which, in turn, is closely related to pyrolysis conditions (Ferrari and Robertson 2000).

The presented results show that the changes in the degree of impregnation and pyrolysis conditions do not significantly affect the degree of the obtained carbon materials order.

\section{Thermal analysis}

Figure 5a shows the TG curves for the initial spent coffee materials obtained according to procedure 1 (Spent $\left.t_{\text {ini }}\right)$ as well as for carbon obtained on the basis of spent ground coffee without $\mathrm{H}_{3} \mathrm{PO}_{4}$ impregnation (sample designated $\mathrm{AC}$ ). The measurements were made in air atmosphere. The course of the curves recorded for the spent ground coffee indicates that the weight loss occurs in three main stages: $20-150{ }^{\circ} \mathrm{C}$ (we assume that it is physically adsorbed water and volatile components); $150-400{ }^{\circ} \mathrm{C}$ and $400-600{ }^{\circ} \mathrm{C}$. The individual stages occur at different speeds (see DTG, Fig. 5c, d and DTA, Fig. 5e, f) and the total content of compounds undergoing desorption or oxidative degradation is $\sim 95 \%$ (Fig. 5a, $\mathrm{c}, \mathrm{e})$.

As the carbon samples were thoroughly washed after the pyrolysis process, the mass losses recorded during the measurements in the temperature range $20-200{ }^{\circ} \mathrm{C}$ are mainly due to the desorption of physically bound water and other volatile organic components. As a matter of fact the phosphoro-organic species that remained in the tested materials may also undergo transformations, however such transformations will be hardly visible due to the significant excess of the carbon amount. The thermogravimetric analysis shows that the mass loss for AC (carbon without the impregnation) was the largest being $\sim 95 \%$ at $800{ }^{\circ} \mathrm{C}$ (the remain $~ 5 \%$ ) while the acid-impregnated carbons at $800{ }^{\circ} \mathrm{C}$ retained about $40 \%$ of their initial mass. As can be seen from the curves in Fig. 5a, the mass loss process for AC slows down significantly at $\sim 700{ }^{\circ} \mathrm{C}$, so it can be assumed that ash and inorganic compounds are the remain. This was the reason for using impregnation.

From the TG curves course it can be seen that physically bound water was desorbed to a temperature of about $150{ }^{\circ} \mathrm{C}$. The weight loss in this temperature range is directly proportional to the acid concentration. This may be due to the higher water content of these materials. The literature reports show that phosphoric acid impregnation causes the formation of so-called phosphate skin (Fig. 6) (Gun'ko et al. 2005), which may constitute a physical barrier during materials drying. The composition analysis made during the SEM/EDX imaging showed the presence of various elements characteristic of the waste organic materials in the tested materials, including phosphorus, which could be incorporated into the carbon structure or form the "phosphate skin" on the surface of the materials. The SEM images show that the particles surface may not be completely covered (Fig. 6b).

As one can see, the surface is mainly uniform and the texture of such material is poorly developed. A similar effect on the active carbons modified with phosphoric acid was observed by Girgis and El-Hendawy (2002). They stated that $\mathrm{H}_{3} \mathrm{PO}_{4}$ creates the so-called" phosphate skin" which can cover the adsorbent internal structure and protects it against excessive burn-off during the activation process. However, this causes a low specific surface area of the adsorbent.

Figure 5 shows the TG, DTG and DTA curves for the tested materials in the temperature range $20-800{ }^{\circ} \mathrm{C}$. All carbons under investigations were thermally stable up to $\sim 420{ }^{\circ} \mathrm{C}$. You can see a clear difference in the materials stability in relation to $\mathrm{AC}$ whose oxidative degradation starts already at $300{ }^{\circ} \mathrm{C}$. The oxidation rate is also different. This 

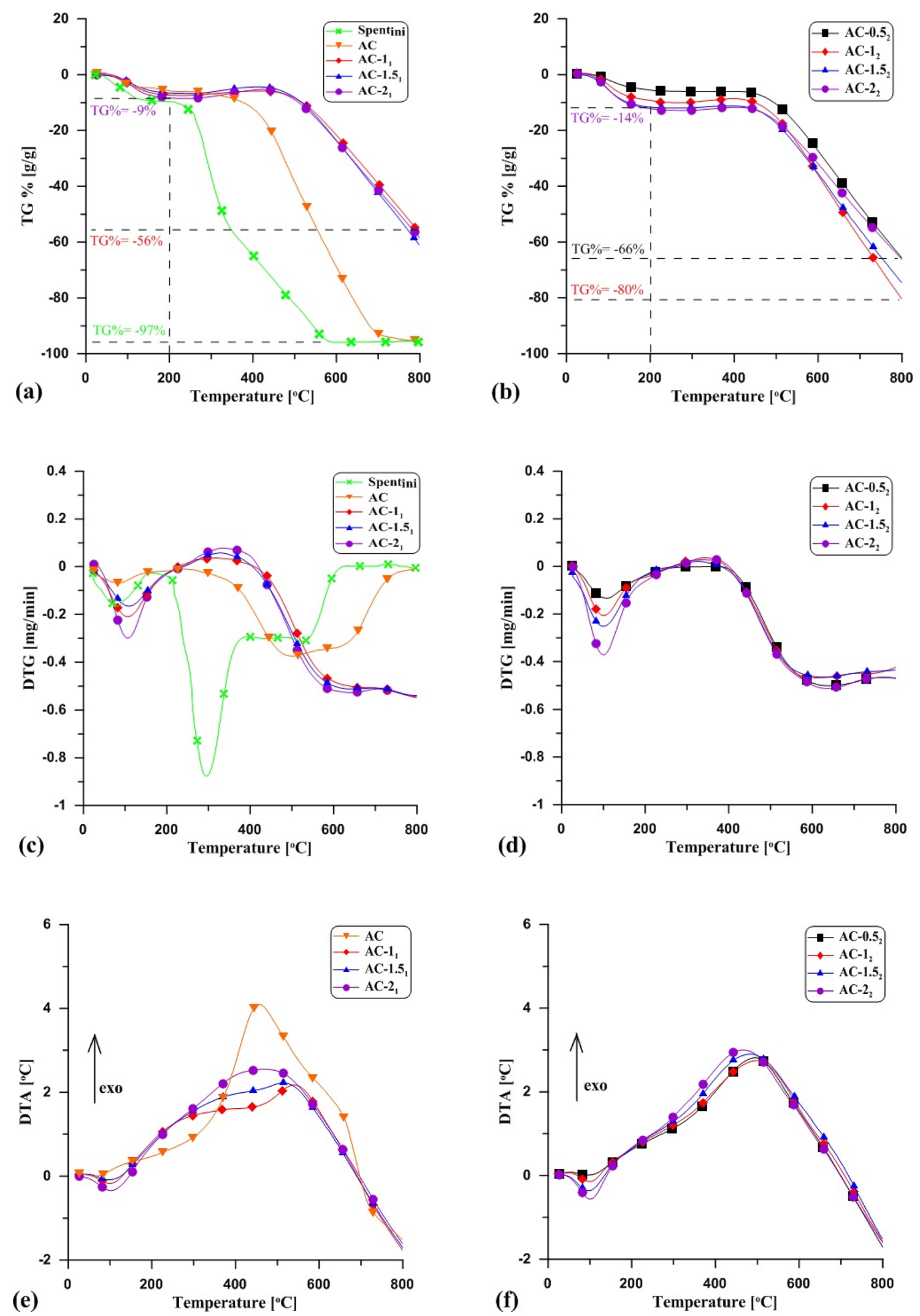

Fig. 5 The course of the TG\% (a, b) DTG $(\mathbf{c}, \mathbf{d})$ DTA $(\mathbf{e}, \mathbf{f})$ curves for the initial spent material (sample Spent ini $_{\text {) }}$ and activated carbons obtained from the spent ground coffee without impregnation and according to $1(\mathbf{a}, \mathbf{c}, \mathbf{e})$ as well as $2(\mathbf{b}, \mathbf{d}, \mathbf{f})$ procedures 
Fig. 6 SEM images of the "phosphate skin" on the AC- $1.5_{1}$ sample (a) and partial covering of the surface $(\mathbf{b})$ magnification $\times 1000$ and $\times 250$, respectively
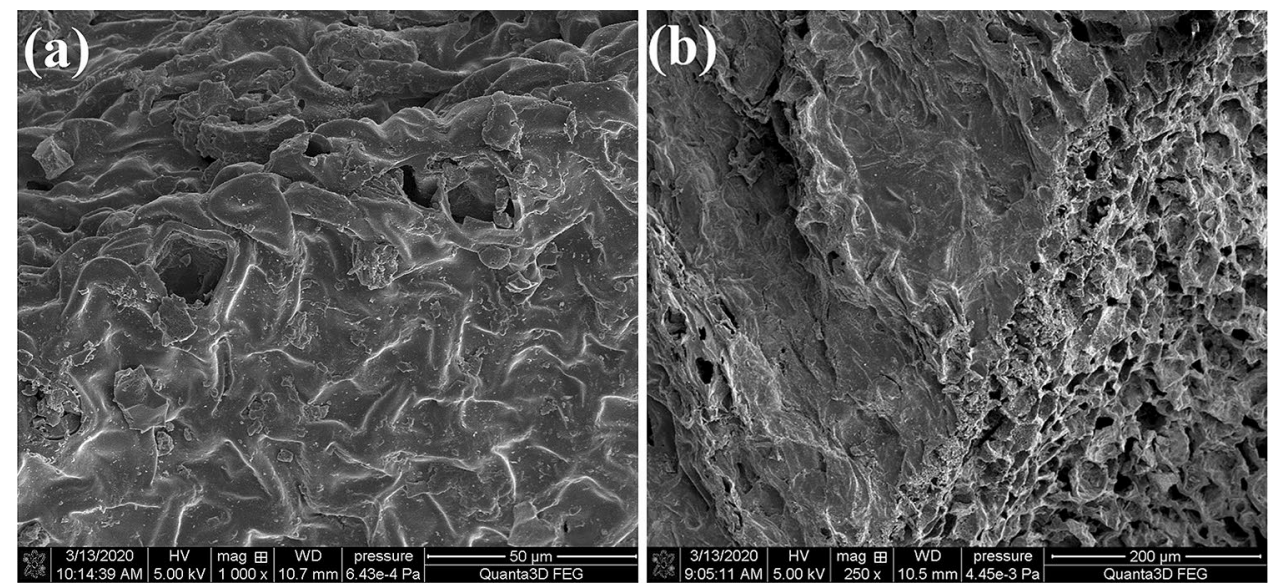

indicates that the structures of the materials changed after the $\mathrm{H}_{3} \mathrm{PO}_{4}$ activation making oxidation difficult. As follows phosphoric acid promotes carbon matter transformation of the thermally stable one. The thermal stability of the products depends on the presence of activating agent $\left(\mathrm{CO}_{2}\right)$. At about $500{ }^{\circ} \mathrm{C}$ the mass loss process begins at different speeds while at $800{ }^{\circ} \mathrm{C}$ the process is not completed.

These changes are confirmed by the DTG (Fig. 5c, d) and DTA (Fig. 5e, f) curves. The DTG curves (Fig. 5c, d) show clearly a depression in the range of $20-150{ }^{\circ} \mathrm{C}$ (with minimum at $T_{\min }=100{ }^{\circ} \mathrm{C}$ ) confirming the evacuation of physically bound water and then the beginning of the peak indicating the weight loss of the carbonaceous material. The course of these curves in the temperature range of $600-800^{\circ} \mathrm{C}$ indicates a diverse burning rate of carbonaceous material. These changes are confirmed by the DTA curves course (Fig. 5e, f). In the initial range from 20 to $150{ }^{\circ} \mathrm{C}$, one can observe the minima indicating the endothermic process of water evaporation, and as the temperature increases, evident peaks associated with the exothermic oxidative degradation of carbon are formed.

Based on the TG\% analysis (Fig. 5a, b), the weight loss of the activated carbons was assessed. The course of the curves shown in both Fig. 5a, b is very similar. It follows that the degree of impregnation affects slightly the stability of the carbon material, e.g. the course of the curves obtained for the materials prepared according to procedure 1 (Fig. 5a) indicates that they contain about $9 \%$ of physically bound water which is desorbed from the surface to a temperature $150{ }^{\circ} \mathrm{C}$ and at a temperature of about $450{ }^{\circ} \mathrm{C}$ carbon oxidative degradation and weight loss begin (for all samples of this series it is about 56\%, Fig. 5a). The samples obtained according to procedure 2 differ in their moisture content (TG\% at $200{ }^{\circ} \mathrm{C}$ from 5 to $14 \%$ ) while the behaviour of the material during further annealing is very similar. The total weight loss for these materials is about $66 \%$ (Fig. 5b).

The comparison of DTA curves (Fig. 5e, f) shows that the materials obtained according to procedure 2 are characterized by a better arrangement of carbon material as evidenced by the clearly developed individual DTA peaks. This results from the greater degree of oxidation caused by the use of $\mathrm{CO}_{2}$. As you can see, the maximum of the DTA peaks shift towards higher temperatures with the impregnation degree increase. This can be due to a protective effect of phosphate skin.

\section{Boehm titration}

The Boehm potentiometric titration method (Boehm et al. 1964) was used to determine the chemical nature of the surface of activated carbons. According to the assumptions, bases with a differentiated strength neutralize acids having $\mathrm{p} K_{\mathrm{a}}$ less or equal to $\mathrm{p} K_{\mathrm{a}}$ of the base. As hydroxides there are used:

- $\mathrm{NaHCO}_{3}\left(\mathrm{p} K_{\mathrm{a}}=6.37\right)$-neutralizes carboxylic acids,

- $\mathrm{Na}_{2} \mathrm{CO}_{3}\left(\mathrm{p} K_{\mathrm{a}}=10.25\right)$-neutralizes carboxylic acids and lactones,

- $\mathrm{NaOH}\left(\mathrm{p} K_{\mathrm{a}}=10.25\right)$ —neutralizes carboxylic acids, lactones and phenols,

- $\mathrm{NaOC}_{2} \mathrm{H}_{5}\left(\mathrm{p} K_{\mathrm{a}}=20.58\right)$-reacts with all oxygen species, even extremely weak acids (of $\mathrm{p} K_{\mathrm{a}}<20.58$ ).

$\mathrm{HCl}$ neutralized all basic groups.

In order to study the $\mathrm{H}_{3} \mathrm{PO}_{4}$ /carbon interactions effect on the activation process, changes in the surface acidic functional groups for the samples with different impregnation degrees $(I)$ and obtained under different pyrolysis conditions were determined (Table 3, Fig. 7). Table 3 shows the content of oxygen functional groups present on the surface of acidimpregnated carbons. The studies pointed out to the acidic nature of carbons. It was found that mostly acidic groups with carboxyl and phenolic structures occur on the surface of the obtained materials. The content of lactone groups is very small. No basic groups were found.

These changes are graphically shown in Fig. 7. 
Table 3 Surface functional groups of the studied activated carbons

\begin{tabular}{lllll}
\hline Sample & $\begin{array}{l}\text { Total number } \\
\text { of acidic groups } \\
(\mathrm{mgR} / \mathrm{g})\end{array}$ & $\begin{array}{l}\text { Carboxyl } \\
\text { groups } \\
(\mathrm{mgR} / \mathrm{g})\end{array}$ & $\begin{array}{l}\text { Phenolic } \\
\text { groups } \\
(\mathrm{mgR} / \mathrm{g})\end{array}$ & $\begin{array}{l}\text { Lactonic } \\
\text { groups } \\
(\mathrm{mgR} / \mathrm{g})\end{array}$ \\
\hline $\mathrm{AC}-1_{1}$ & 1.59 & 1.2 & 0.03 & 0.21 \\
$\mathrm{AC}-1.5_{1}$ & 1.52 & 1.27 & 0.02 & 0.15 \\
$\mathrm{AC}-2_{1}$ & 1.49 & 1.4 & 0.01 & 0.06 \\
$\mathrm{AC}-0.5_{2}$ & 1.69 & 0.68 & 0.58 & 0.33 \\
$\mathrm{AC}-1_{2}$ & 1.53 & 1.09 & 0.29 & 0.11 \\
$\mathrm{AC}-1.5_{2}$ & 1.45 & 1.13 & 0.12 & 0.09 \\
$\mathrm{AC}-2_{2}$ & 1.4 & 1.25 & 0.08 & 0.01 \\
\hline
\end{tabular}

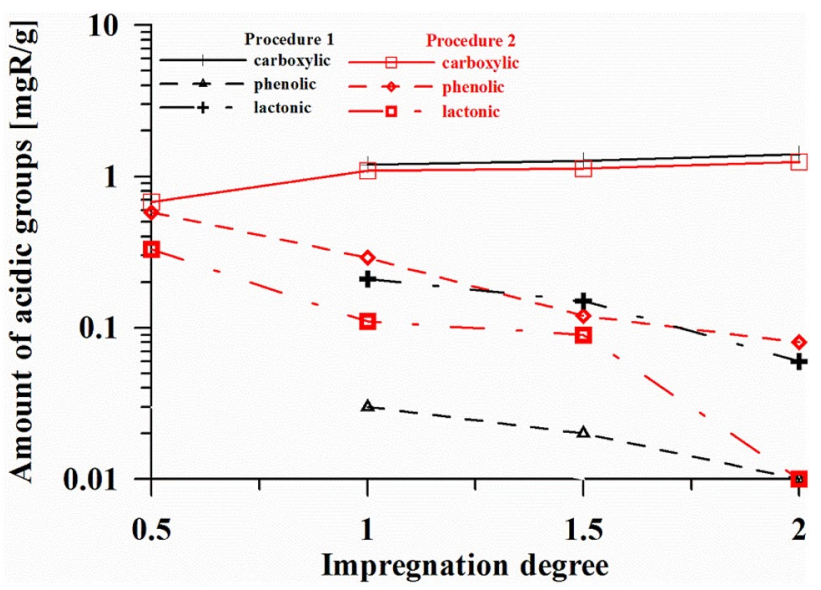

Fig. 7 Graphical presentation of changes in the number of functional groups on the surface of acid-impregnated carbons

It can be seen that mainly carboxyl groups (0.68-1.4 $\mathrm{mgR} / \mathrm{g}$ ) are found on the surface of the studied materials. Their number increases with the increase of $I$. At the same time, the number of lactone and phenol groups decreases systematically. It is known that other oxygen groups may also be present on the surface of active carbons, e.g. aldehyde or ketone groups, etc. However, they were not determined in the presented studies. Probably such structures are present on the surface of tested carbons because the total number of groups determined with $\mathrm{NaOH}$ (e.g. for $\mathrm{AC}-1_{1}=1.59$ $\mathrm{mgR} / \mathrm{g}$, Table 3 ) is larger than the sum of the carboxyl, phenolic and lactonic groups $(1.2+0.03+0.21=1.44 \mathrm{mgR} / \mathrm{g})$.

\section{SEM}

The analysis of SEM images of the selected materials (Figs. 6, 8) shows that they have a heterogeneous structure. Activated carbon particles have different shapes and their surface is folded, rough and contains numerous gaps and cavities of various sizes (Fig. 8a). Exemplary, for the AC-1.5 sample the cavities with the dimensions about 1, 5 or $20 \mu \mathrm{m}$ were observed (Fig. 8a, c).
Increasing the degree of impregnation (comparison of Fig. $8 b, c)$ course makes the surface smoother, more homogeneous. In the case of materials additionally activated using $\mathrm{CO}_{2}$ (sample AC-1.5 , Fig. 8d) a larger surface heterogeneity is observed. The carbon globules contain particles of various sizes and numerous cracks and crevices are visible on the surface.

The EDX microanalysis enables surface and volume identification (both qualitative and quantitative) of chemical elements contained in the tested material. Table 4 presents the results of the elemental composition analysis of selected materials. As can be seen the composition of the studied coals is typical of the organic carbon materials. They contain mainly carbon $(\sim 70-74 \%)$, oxygen $(\sim 13.5-17 \%)$, phosphorus $(\sim 5.5-8.7 \%)$, nitrogen $(\sim 4 \%)$ and calcium $(\sim 0.1-0.25 \%$, Table 4). The presence of the other elements is due to the composition of the starting organic material. The relatively high oxygen content confirms the existence of the surface oxygen groups whose presence was confirmed by the potentiometric titration (Table 3). The source of phosphorus is double. A small amount of phosphorus can originate from the starting waste material. Lee et al. (Lee et al. 2017) found in the biochar from palm oil sludge the presence of the main elements in the amount: C: $71.99 \%, \mathrm{O}: 21.09 \%, \mathrm{Mg}: 0.56 \%$, P: $0.41 \%$, and many others. However, the main reason for the presence of phosphorus is earlier impregnation. Owing to this phosphorus could be built into the carbon structure and/or create a surface phosphate skin. As can be seen (Table 4) the phosphorus content increases with the increasing impregnation degree. At the same time the analysis of the data proved that the use of $\mathrm{CO}_{2}$ (procedure 2) causes that the amount of phosphorus is smaller by about $25 \%$ in the materials of the same impregnation degree than those obtained in the nitrogen atmosphere (procedure).

\section{Conclusions}

Based on the carried out research it was found that solid coffee wastes (spent coffee grounds) are a good starting material for the production of activated carbons. The use of chemical activation with phosphoric $\operatorname{acid}(\mathrm{V})$ enabled the creation of a well-developed microporous structure in the obtained carbon materials. The increase in impregnation with $\mathrm{H}_{3} \mathrm{PO}_{4}$ resulted in an increase in both the burning rate and porosity. From the surface development point of view, the use of $\mathrm{CO}_{2}$ as an additional oxidizing agent has proved to be more effective (procedure 2). As a result, the carbons with the surface area from 407.8 to $720.9 \mathrm{~m}^{2} / \mathrm{g}$ were obtained characterized by about $80 \%$ share of micropores.

The thermal analysis of the tested carbons showed that these materials were more thermally stable than the nonimpregnated carbons. This justifies the use of $\mathrm{H}_{3} \mathrm{PO}_{4}$ as the 
Fig. 8 SEM images for AC-1.5 (a, c), $\mathrm{AC}-1_{1}$ (b) and $\mathrm{AC}-1.5_{2}$ (d) carbon samples (magnification: $\times 2500$ )


Table 4 Results of EDS chemical composition microanalysis

\begin{tabular}{lllll}
\hline Element/Line & $\mathrm{AC}-1_{1}(\% \mathrm{w} / \mathrm{w})$ & $\mathrm{AC}-2_{1}(\% \mathrm{w} / \mathrm{w})$ & $\mathrm{AC}-1_{2}(\% \mathrm{w} / \mathrm{w})$ & $\mathrm{AC}-2_{2}(\% \mathrm{w} / \mathrm{w})$ \\
\hline $\mathrm{C} / \mathrm{K}$ & 71.21 & 69.77 & 76.47 & 74.44 \\
$\mathrm{O} / \mathrm{K}$ & 17.07 & 17.12 & 13.59 & 14.57 \\
$\mathrm{P} / \mathrm{K}$ & 7.14 & 8.69 & 5.52 & 6.64 \\
$\mathrm{~N} / \mathrm{K}$ & 4.05 & 3.94 & 4.03 & 3.9 \\
$\mathrm{Ca} / \mathrm{K}$ & 0.27 & 0.25 & 0.13 & 0.24 \\
$\mathrm{Na} / \mathrm{K}$ & 0.06 & 0.03 & 0.02 & 0.03 \\
$\mathrm{Mg} / \mathrm{K}$ & 0.12 & 0.2 & 0.19 & 0.16 \\
$\mathrm{~K} / \mathrm{K}$ & 0.08 & 0.01 & 0.05 & 0.02 \\
\hline
\end{tabular}

activating agent. Thermal stability of the obtained materials does not depend on the impregnation degree but on the procedure (with or without of $\mathrm{CO}_{2}$ as an oxidizing agent).

The SEM studies of the activated carbons surface have shown the presence of numerous roughness, crevices, cavities and channels. Carbons acidic character was proved. It was found that the acidic groups with carboxyl and phenolic structures are present on the surface. Based on the phase composition analysis it was found that the obtained carbon materials were characterized by an amorphous structure.

Acknowledgements The authors of the paper thank very much to Prof. V.M. Gun'ko from the Institute of Surface Chemistry of the National
Academy of Sciences of Ukraine in Kiev for providing their own software that was used in the interpretation of the data presented in this paper.

\section{Compliance with ethical standards}

Conflict of interest On behalf of all authors, the corresponding author states that there is no conflict of interest.

Open Access This article is licensed under a Creative Commons Attribution 4.0 International License, which permits use, sharing, adaptation, distribution and reproduction in any medium or format, as long as you give appropriate credit to the original author(s) and the source, provide a link to the Creative Commons licence, and indicate if changes 
were made. The images or other third party material in this article are included in the article's Creative Commons licence, unless indicated otherwise in a credit line to the material. If material is not included in the article's Creative Commons licence and your intended use is not permitted by statutory regulation or exceeds the permitted use, you will need to obtain permission directly from the copyright holder. To view a copy of this licence, visit http://creativecommons.org/licenses/by/4.0/.

\section{References}

Alslaibi TM, Abustan I, Ahmad MA, Foul AA (2013) A review: production of activated carbon from agricultural byproducts via conventional and microwave heating. J Chem Technol Biotechnol 88:1183-1190. https://doi.org/10.1002/jctb.4028

Arampatzidou AC, Deliyanni EA (2016) Comparison of activation media and pyrolysis temperature for activated carbons development by pyrolysis of potato peels for effective adsorption of endocrine disruptor bisphenol-A. J Colloid Interf Sci 466:101-112. https://doi.org/10.1016/j.jcis.2015.12.003

ASTM D2854-09 (2014) Standard test method for apparent density of activated carbon. ASTM International, West Conshohocken

Baquero MC, Giraldo L, Moreno JC, Suárez-García F, MartínezAlonso A, Tascón JMD (2003) Activated carbons by pyrolysis of coffee bean husks in presence of phosphoric acid. J Anal Appl Pyrol 70:779-784. https://doi.org/10.1016/S0165-2370(02)00180 $-8$

Benaddi H, Legras D, Rouzaud JN, Beguin F (1998) Influence of the atmosphere in the chemical activation of wood by phosphoric acid. Carbon 36:306-309. https://doi.org/10.1016/s0008 -6223(98)80123-1

Boehm HP, Diehl E, Heck W, Sappok R (1964) Surface oxides of carbon. Angew Chem 3:669-677. https://doi.org/10.1002/anie.19640 6691

Boudrahem F, Soualah A, Aissani-Benissad F (2011) Pb(II) and Cd(II) removal from aqueous solutions using activated carbon developed from coffee residue activated with phosphoric acid and zinc chloride. J Chem Eng Data 56:1946-1955. https://doi.org/10.1021/ je1009569

CRC Handbook of Chemistry and Physics (2003) 84th edn. Chemical Rubber Publishing Company: Boca Raton

Ferrari AC, Robertson J (2000) Interpretation of Raman spectra of disordered and amorphous carbon. Phys Rev B 61:14095-14107. https://doi.org/10.1103/PhysRevB.61.14095

Ferrari AC, Robertson J (2004) Raman spectroscopy of amorphous, nanostructured, diamond-like carbon, and nanodiamond. Philos Trans R Soc Lond A 362:2477-2512. https://doi.org/10.1098/ rsta.2004.1452

Franca AS, Oliveira LS (2009) Coffee processing solid wastes: current uses and future perspectives. Agric Wastes 9:155-189

Girgis BS, El-Hendawy ANA (2002) Porosity development in activated carbons obtained from date pits under chemical activation with phosphoric acid. Micropor Mesopor Mat 52:105-117. https://doi. org/10.1016/S1387-1811(01)00481-4

Gregg SJ, Sing KSW (1982) Adsorption, surface area and porosity, 2nd edn. Academic Press, London

Gun'ko VM (2000) Consideration of the multicomponent nature of adsorbents during analysis of their structural and energy parameters. Theor Exp Chem 36:319-324. https://doi. org/10.1023/A:1005264427135

Gun'ko VM (2014) Composite materials: textural characteristics. Appl Surf Sci 307:444-454. https://doi.org/10.1016/j.apsus c.2014.04.055
Gun'ko VM, Mikhalovsky SV (2004) Evaluation of slitlike porosity of carbon adsorbents. Carbon 42:843-849. https://doi.org/10.1016/j. carbon.2004.01.059

Gun'ko VM, Turov VV (2013) Nuclear magnetic resonance studies of interfacial phenomena. Taylor \& Francis, New York

Gun'ko VM, Seledets O, Skubiszewska-Zięba J, Zarko VI, Leboda R, Janusz W, Chibowski S (2005) Phosphorus-containing carbon deposits on silica gel Si-100. Micropor Mesopor Mat 87:133-145

Gun'ko VM, Do DD (2001) Characterizations of pore structure of carbon adsorbents using regularisation procedure. Colloid Surf A 193:71-83. https://doi.org/10.1016/S0927-7757(01)00685-9

Hesas RH, Daud WMAW, Sahu JN, Arami-Niya A (2013) The effects of a microwave heating method on the production of activated carbon from agricultural waste: a review. J Anal Appl Pyrol 100:1-11. https://doi.org/10.1016/j.jaap.2012.12.019

Illy E (2002) The complexity of coffee. Scientific American Inc, New York, pp 86-91

Ioannidou O, Zabaniotou A (2007) Agricultural residues as precursors for activated carbon production - a review. Renew Sustain Energy Rev 11:1966-2005. https://doi.org/10.1016/j.rser.2006.03.013

Jankowska H, Świątkowski A, Choma J (1991) Active Carbon. Ellis Horwood, New York

Kang S, Jian-chun J, Dan-dan C (2011) Preparation of activated carbon with highly developed mesoporous structure from Camellia oleifera shell through water vapor gasification and phosphoric acid modification. Biomass Bioenergy 35:3643-3647. https://doi. org/10.1016/j.biombioe.2011.05.007

Kostecka J, Koc-Jurczyk J, Brudzisz K (2014) Waste management in Poland and European Union. Archiwum Gospodarki Odpadami i Ochrony Środowiska (in polish) 16:1-10

Leboda R, Charmas B, Skubiszewska-Zieba J, Chodorowski S, Oleszczuk P, Gun'ko VM, Pokrovskiy VA (2005) Carbon-mineral adsorbents prepared by pyrolysis of waste materials in the presence of tetrachloromethane. J Colloid Interf Sci 284:39-47. https://doi. org/10.1016/j.jcis.2004.09.052

Lee XJ, Lee LY, Hiew BYZ, Gan S, Thangalazhy-Gopakumar S, Ng HK (2017) Multistage optimizations of slow pyrolysis synthesis of biochar from palm oil sludge for adsorption of lead. Bioresour Technol 245:944-953. https://doi.org/10.1016/j.biort ech.2017.08.175

Li Y, Zhang X, Yang R, Li G, Hu C (2015) The role of $\mathrm{H}_{3} \mathrm{PO}_{4}$ in the preparation of activated carbon from $\mathrm{NaOH}$-treated rice husk residue. RSC Adv 5:32626-32636. https://doi.org/10.1039/x0xx0 0000x

Liou TH, Wu SJ (2009) Characteristics of microporous/mesoporous carbons prepared from rice husk under base-and acid-treated conditions. J Hazard Mater 171:693-709. https://doi.org/10.1016/j. jhazmat.2009.06.056

Liu XY, Huang M, Ma HL, Zhang ZQ, Gao JM, Zhu YL, Han XJ, Guo XY (2010) Preparation of a carbon-based solid acid catalyst by sulfonating activated carbon in a chemical reduction process. Molecules 15:7188-7196. https://doi.org/10.3390/molecules15107188

McKee DW (1991) Oxidation protection of carbon materials. Chem Phys Carbon 23:173-232

Myglovets M, Poddubnaya OI, Sevastyanova O, Lindström ME, Gawdzik B, Sobiesiak M, Tsyba MM, Sapsay VI, Klymchuk DO, Puziy AM (2014) Preparation of carbon adsorbents from lignosulfonate by phosphoric acid activation for the adsorption of metal ions. Carbon 80:771-783. https://doi.org/10.1016/j.carbo n.2014.09.032

Nowicki P, Kaźmierczak-Raźna J, Skibiszewska P, Wiśniewska M, Nosal-Wiercińska A, Pietrzak R (2016) Production of activated carbons from biodegradable waste materials as an alternative way of their utilization. Adsorption 22:489-502. https://doi. org/10.1007/s10450-015-9719-z 
Oh SG, Rodriguez NM (1993) In situ electron microscopy studies of the inhibition of graphite oxidation by phosphorus. J Mater Res 8:2879-2888. https://doi.org/10.1557/JMR.1993.2879

Okamura M, Takagaki A, Toda M, Kondo JN, Domen K, Tatsumi T, Hara M, Hayashi S (2006) Acid-catalyzed reactions on flexible polycyclic aromatic carbon in amorphous carbon. Chem Mater 18:3039-3045. https://doi.org/10.1021/cm0605623

Oyedun AO, Lam KL, Gebreegziabher T, Hui CW (2013) Optimization of multi-stage pyrolysis. Appl Therm Eng 61:123-124. https://doi. org/10.1016/j.applthermaleng.2013.03.043

Puziy AM (2011) Methods of production, structure, and physicochemical characteristics of phosphorylated carbon adsorbents. Theor Exp Chem 47:277-291. https://doi.org/10.1007/s1123 7-011-9216-8

Puziy AM, Poddubnaya OI, Martínez-Alonso A, Suárez-García F, Tascón JMD (2002) Synthetic carbons activated with phosphoric acid: I. Surface chemistry and ion binding properties. Carbon 40:1493-1505. https://doi.org/10.1016/S0008-6223(01)00317-7

Reffas A, Bernardet V, David B, Reinerta L, Lehocine MB, Dubois M, Batisse N, Duclaux L (2010) Carbons prepared from coffee grounds by $\mathrm{H}_{3} \mathrm{PO}_{4}$ activation: characterization and adsorption of methylene blue and Nylosan Red N-2RBL. J Hazard Mater 175:779-788. https://doi.org/10.1016/j.jhazmat.2009.10.076
Sing KSW (1982) Reporting physisorption data for gas/solid system with special reference to the determination of surface area and porosity. Pure Appl Chem 54:2201-2214. https://doi.org/10.1351/ pac198254112201

Skubiszewska-Zięba J, Charmas B, Leboda R, Gun'ko VM (2012) Carbon-mineral adsorbents with a diatomaceous earth/perlite matrix modified by carbon deposits. Micropor Mesopor Mat 156:209-216. https://doi.org/10.1016/j.micromeso.2012.02.038

Yang J, Roy C (1996) A new method for DTA measurement of enthalpy change during the pyrolysis of rubbers. Thermochim Acta 288:155-168. https://doi.org/10.1016/S0040-6031(96)03017-1

Zielińska A, Oleszczuk P, Charmas B, Skubiszewska-Zięba J, Pasieczna-Patkowska S (2015) Effect of sewage sludge properties on the biochar characteristic. J Anal Appl Pyrol 11:201-213. https://doi. org/10.1016/j.jaap.2015.01.025

Publisher's Note Springer Nature remains neutral with regard to jurisdictional claims in published maps and institutional affiliations. 